\title{
Chemical Literacy Skill of High School Students on Solution Chemistry
}

\author{
Senna Prasemmi ${ }^{1}$, Sri Rahayu ${ }^{1 *}$, Fauziatul Fajaroh ${ }^{1}$, and Saeed Almuntasheri ${ }^{2}$ \\ ${ }^{1}$ Department of Chemistry Education, Faculty of Mathematics and Natural Science, \\ Universitas Negeri Malang, Jl. Semarang No. 5, Malang, 65145, Indonesia, \\ 2 Faculty of Education, Albaha University, Saudi Arabia \\ *E-mail: sri.rahayu.fmipa@um.ac.id
}

Received: 24 February 2021; Accepted: 29 March 2021; Published: 30 June 2021

\begin{abstract}
This research aimed to develop a multiple-choice chemical literacy test on solution chemistry as an instrument that specifically focuses on learners' knowledge and competency aspects; applying the test instrument by surveying 12th-grade high school students. The development of the test instrument adapted the R\&D model by Borg and Gall. The Cronbach's Alpha reliability of the test was obtained after small-scale and wide-scale trials are 0.793 and 0.833 , respectively, with 35 valid items. Data were collected using random cluster sampling with a total of 463 respondents. The result shows that the mean score of chemical literacy for the students in this study is 46.27. This indicated that the students' level of chemical literacy is low, and further improvement is required.
\end{abstract}

Keywords: chemical literacy, chemical literacy test, solution chemistry

DOI: https://doi.org/10.15575/jtk.v6i1.10392

\section{Introduction}

Scientific literacy refers to a person's capability to understand laws, theories, phenomena, and scientific things in the surrounding environment in order to make practical decisions in their life (Dragos \& Mih, 2015; Celik, 2014; Demir, 2016). This decision is based on the evaluation of information and arguments that presented by scientists and media through the use of evidence and collected data. This helps to properly participate in public policies that have a direct impact on their lives. scientific literacy was defined by Organization for Economic Cooperation and Development (OECD) as someone's ability to understand and engage in discussions on various issues in relation to science and technology. Three competencies were identified including, the explanation of scientific phenomena, designing scientific investigations or inquiries, and scientific interpretation of data. These three competencies require knowledge (content, procedural, and epistemic). Scientific literacy has an important role in making decisions on science issues that occur in society making it the main focus of science education (Bossér et al., 2015; Vieira \& Vieira, 2014; Fives et al., 2014). Chemical literacy is a crucial part of scientific literacy, and one of the main objectives of chemistry education (Cigdemoglu et al., 2017).

One of the implications of making chemical literacy as a goal of chemistry education is that there must be an appropriate assessment to measure chemical literacy (Muntholib, 2020). Therefore, several assessment frameworks have been developed worldwide (Cigdemoglu \& Geban, 2015; Shwartz et al., 2006; OECD, 2016; Cigdemoglu et al., 2017; Fives et al., 2014; Benjamin et al., 2015). Program for International Student Assessment (PISA) is a comprehensive international assessment aimed at measuring scientific literacy, 
launched by the OECD. The PISA framework divides scientific literacy into four interrelated aspects. These include context (personal, national, and global), knowledge (content, procedural, and epistemic), competence (explaining phenomena scientifically, evaluating and designing scientific investigations, and interpreting scientific data and evidence), and attitudes (interests, attention, and responses to science, technology, and current issues related to the social science of students) (OECD, 2016). Shwartz et al. (2006) developed a framework that covers for aspects, namely (1) chemistry in context, (2) scientific and chemical content knowledge, (3) higher-order learning skills, and (4) affective aspects. Each of these aspects suggested ideas for a chemically literate person.

The chemical literacy framework of Shwartz et al. (2006) matches with the OECD (2016) scientific literacy framework (Rahayu, 2017; Cigdemoglu, et al., 2017), but the framework of OECD is more popular, simpler, and more explicit than the framework of Shwartz et al. (Muntholib, 2020). Several chemical literacy instruments have been developed based on this framework. Shwartz et al. (2006) measured the five levels of chemical literacy of students in grades 10-12 in Israel. These involve scientific illiteracy, nominal scientific literacy, functional scientific literacy, conceptual scientific literacy, and multi-dimensional scientific literacy. The assessment tools developed were multiple-choice questions, open-ended questions, and the use of a Likert scale. According to these authors, it is difficult to assess all aspects and components of chemical literacy, and thus each level of chemical literacy is assessed using several assessment tools. The topics chosen were the properties of matter particles, chemical reactions, student's ability to use chemical laws and theories to explain phenomena, and the application of chemistry in everyday life. Thummathong and Tathong (2018) made chemical literacy instruments containing basic chemistry topics, including atomic theory, the periodic table, chemical bonds, moles and molarity, stoichiometry, gases, chemical equilibrium, acid-base, electrochemical reactions, thermodynamics, and chemical kinetics. They developed a test that consists of multiple choice, essays, and a Likert scale to assess students' attitudes. The instrument was used to measure the chemical literacy of firstyear engineering students in Thailand. The measured aspects of chemical literacy were (a) knowledge and understanding of chemical content (knowledge and understanding of the relationship between chemistry, technology, and society), (b) the application of chemistry in everyday life (application of analytical thinking and application of reasoning), and (c) awareness (awareness of morals and responsibility, and attitudes towards chemistry). Other studies such as Cigdemoglu et al. (2017) developed an open-ended test instrument on the topic of acid-base concepts to measure the chemical literacy of grade 11 students. The test follows the PISA-2006 framework. Muntholib (2020) developed a multiple-choice chemical literacy test instrument on the topic of chemical kinetics using a combination of the framework of OECD (2016) and Shwartz et al (2006). Measurements were made based on aspects of knowledge and competence. Several other researchers who developed chemical literacy test instruments using the similar frameworks, were Nurjananto and Kusumo (2015) on chemistry carbon, Ad'hiya and Laksono (2018), Sadhu and Laksono (2018) on chemical equilibrium, Yustin and Wiyarsi (2019) on chemical bonds. However, lack of research that was developed on a chemical literacy test instruments for the learners' knowledge and competency of chemistry solution topics.

Research has indicated that using a multiplechoice test can be one of the most efficient way to identify student conceptions (Wattanakasiwich et al., 2013). This type of testing allows time for researchers to perform data analysis and provides quantitative results that can be compared (Wattanakasiwich et al., 2013). However, weaknesses of multiplechoice test can be found. For example, students can answer fraudulently. To overcome this, the researcher may carry out several trials and an adequate number of participants so that a decent product can be obtained. 
Several multiple-choice tests had been developed in identifying student conceptions. For instance, Mutlu and Sesen (2015) examined student conceptions of thermochemistry, chemical kinetics, chemical equilibrium, acid-base and electrochemistry concepts. Rahayu et al. (2011) studied student conception of electrochemistry concepts, while Muntholib et al. (2018) conducted a multiple-choice test about chemical kinetics and acid-base concepts. The study conducted by Nahadi and Ulum (2018) discovered concepts of learners in relation to thermochemistry. These studies revealed that multiple-choice tests had long been used, were in great demand, and widely administered. The aspects of knowledge and chemical literacy competencies focus on chemical knowledge and scientific cognitive inquiry abilities (Muntholib, 2020). These two aspects can be assessed using a multiplechoice test format as in the OECD (2015) framework.

Based on PISA survey data, Indonesia's achievement in 2006 was ranked $50^{\text {th }}$ out of 57 countries, in 2009 was ranked $57^{\text {th }}$ out of 63 countries, it was $64^{\text {th }}$ out of 65 countries in 2012 , and it was $64^{\text {th }}$ out of 72 countries in 2015 (Rahayu, 2017). The latest PISA scientific literacy results in 2018, Indonesia's score has decreased compared to the previous year, thus placing Indonesia in the $70^{\text {th }}$ rank out of 78 countries (OECD, 2018). Such data indicate that the scientific literacy skills of Indonesian students need to be improved. The concept of science education is very broad, and thus specific subjects in science classrooms must contribute to the goal of increasing students' scientific literacy (Celik, 2014). For example, learning chemistry in the classroom contributes to improving chemical literacy in particular and scientific literacy in general. To improve students' literacy of science in Indonesia, inquiry-based learning has been suggested as an ideal scientific approach. Based on regulation number 22 of Kemdikbud (2016a), the stages of inquiry-based learning approach can be through (1) observing, (2) asking, (3) trying, (4) reasoning, and (5) communicating. However, in practice students have difficulty achieving learning goals that lead to improving their chemical literacy, especially designing and evaluating scientific inquiry and interpreting scientific data and evidence. This is in contrast of learning using the lecture method, when the goal is to convey important concepts to the learners (Muntholib, 2018).

One of the main topics of chemistry in Senior High School in Indonesia is chemistry solution (Kemdikbud, 2016a). Chemistry solution topic is spread over several levels (Kemdikbud, 2016b), the topic was taught in class 10 (electrical conductivity in solutions), class 11 (acid-base solutions, buffer solutions, and salt solutions), and class 12 (colligative properties of solutions). There are several applications of the chemical concept of solutions in everyday life, for example, the process of blood dialysis, filling the battery, body $\mathrm{pH}$, food preservation, and gastric medicine. This shows that chemistry is closely related to everyday life. In addition, this topic also contains aspects of scientific literacy so that it can be used as a study for measuring student scientific literacy. This can be a reason to improve students' chemical literacy. Efforts to improve students' chemical literacy require a test instrument, and thus, a chemical literacy test of chemistry solution is developed for this research.

Development of chemical literacy test instrument assessment in the current research combines the OECD's scientific literacy framework (2016) and Shwartz's chemical literacy framework (2006), which can be seen in Table 1. Selection of this framework is due to the fact that OECD's framework is simple, explicit, and the most widely used, while the Shwartz framework is more specific and detailed. In this research, the focus of the instrument is on context, knowledge, and competency aspects, but without attitude aspects, although the assessment of attitude aspects can be done separately (Muntholib, 2018; Thummathong \& Tathong, 2018). 


\section{Research Method}

\subsection{Instrument Development}

The development of the test instrument in this research combines the framework of OECD (2016) and Shwartz et al. (2006) as can be shown in Table 1. It covered all the aspects that were suggested by the framework except the attitude aspects. Figure 1 highlights the stages of developing the chemical literacy test instrument that was adapted from the R\&D model of Borg and Gall (1983).

The preliminary study stage emphasis on reviewing the literature of international journal articles and relevant books on chemistry solution, chemical literacy, scientific literacy, PISA, instrument development, assessment, and instrument validation.

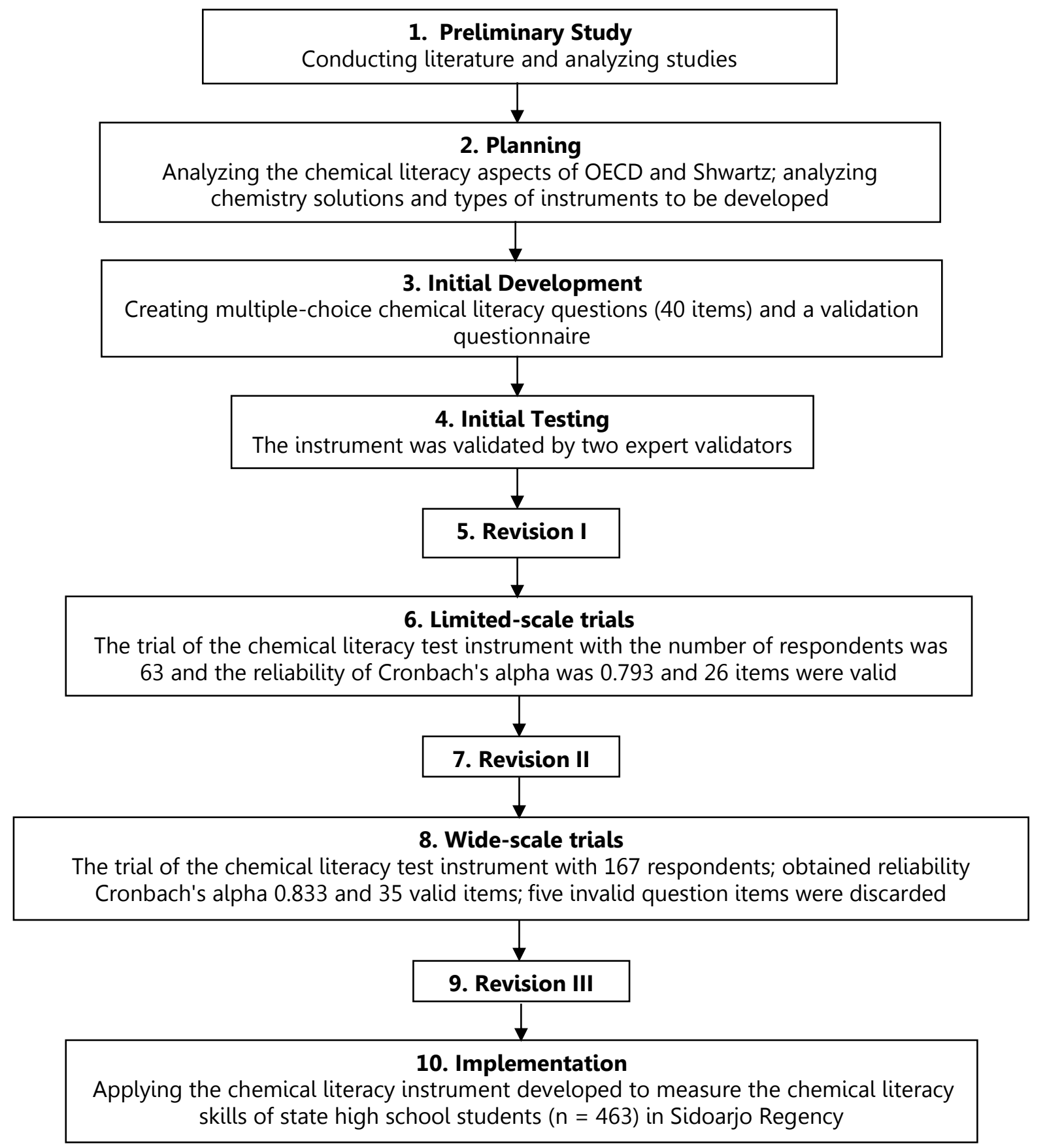

Figure 1. Stages of Developing Chemical Literacy Test Instrument 
Tabel 1. Chemical Literacy Framework of OECD (2016) and Shwartz et al. (2006)

Context
Individual, local/national, and global issues. This
may involve issues that have occurred daily or
issues that have already occurred which require an
understanding of science and technology

\section{Knowledge}

An understanding of the main facts, concepts, and explanatory theory that builds the foundation of scientific knowledge. Knowledge in the form of knowledge about the universe and technological artifacts (content knowledge), knowledge of how ideas are generated (procedural knowledge), and understanding of the rationale that underlies these procedures and justification of their use (epistemic knowledge)

\section{Competency}

The ability to explain scientific phenomena, evaluate and design scientific inquiry, and the ability to interpret data and to provide scientific evidence

\section{Attitudes}

A set of attitudes towards science demonstrated with an interest in science and technology, assessing a scientific approach to appropriate inquiry, and perceptions and awareness of environmental issues

Then at the planning stage, an analysis of chemical literacy aspects was carried out based on OECD and Shwartz, an analysis of chemistry solution materials, the context of the problem by the chemistry curriculum of high schools in Indonesia, determining the type of instrument in the form of multiplechoice in Indonesian and the number of question items which will be developed.

The chemical literacy test instrument developed consists of five contexts with several item questions for each context covering aspects of knowledge and competence with distribution according to Table 2. The number of items developed in the initial draft was 40 items.

\section{Chemistry in Context}

Framework Shwartz

- Knowledge covering the importance of chemistry in explaining phenomena in everyday life

- Use of understanding of chemistry in everyday life, such as consumers of new products and technologies, how to make a decision-based chemistry, and the participation in social debates related to existing chemical issues

- An understanding of the relationship between chemical innovation and social processes

\section{Scientific and Chemical Content Knowledge}

An understanding of scientific ideas in general (chemistry is an experimental discipline, and chemistry is used to explain existing phenomena) and understanding of chemical characteristics/key ideas (explaining macroscopic phenomena in the molecular structure of matter, investigating the dynamics of processes, reactions, and changes in energy during the reaction process, describing life in terms of chemical structures and life system processes)

\section{Higher-Order Learning Skills}

The ability to ask questions, find related information when needed, and be able to analyze the disadvantages/benefits in every debate

\section{Affective aspects}

A view of chemistry and its applications which impartial and realistic. Expressions of interest in chemistry issues, especially in informal framework (such as TV programs)

Initial testing was carried out by expert validators to determine the content validity of the test instruments. This validity includes four aspects of assessment, 1) suitability of indicators, aspects of literacy, and cognitive demand; 2) scientifically correct material; 3) clarity of the question on the question (clarify); 4) the effectiveness of the used language. In this validation, a score was allocated for each of the developed question items. Score 4 is given if all aspects of the assessment were complete. At this stage, the researcher receives suggestions/input from the validator and then makes improvements or revisions which were also discussed with the chemistry lecturer. 
Table 2. Context, Indicator, Aspects of Chemical Literacy, Item Numbers

\begin{tabular}{|c|c|c|c|}
\hline Context & Indicator & $\begin{array}{l}\text { Aspects of } \\
\text { Chemical } \\
\text { Literacy* }\end{array}$ & $\begin{array}{l}\text { Item } \\
\text { Number }\end{array}$ \\
\hline Is it true that & Determining the solute in a solution & ID; CK & 1 \\
\hline \multirow{6}{*}{$\begin{array}{l}\text { Carbon dioxide is } \\
\text { the mastermind } \\
\text { behind the Global } \\
\text { Warming issue? }\end{array}$} & Reading scientific data in the form of graphs & ID; EK & 2 \\
\hline & Reading scientific data in the form of graphs & ID; EK & 3 \\
\hline & Evaluating claims based on data and scientific evidence & EP; EK & 4 \\
\hline & Determining the mass of the solute in a solution & $E D ; C K$ & 5 \\
\hline & Evaluating analogies based on the knowledge they have & ED; EK & 6 \\
\hline & $\begin{array}{l}\text { Summing up the properties of the solution based on the } \\
\text { reaction equation }\end{array}$ & $E P ; E K$ & 7 \\
\hline Starting Rare: & Determining the sample of a solution & ID; CK & 8 \\
\hline Cassia vera from & Determining the solvent of a solution & ID; CK & 9 \\
\hline Kerinci the & Determining the solute of a solution & ID; CK & 10 \\
\hline Primadonna of the & Determining the concentration of the solute in a solution & $\mathrm{ED} ; \mathrm{CK}$ & 11 \\
\hline \multirow[t]{4}{*}{ World } & $\begin{array}{l}\text { Formulating conclusions based on the solution's boiling } \\
\text { point data }\end{array}$ & EP; EK & 12 \\
\hline & Determining variables based on investigative questions & $\mathrm{ED} ; \mathrm{PK}$ & 13 \\
\hline & Determining variables based on investigative questions & $\mathrm{ED} ; \mathrm{PK}$ & 14 \\
\hline & Determining variables based on investigative questions & ED; PK & 15 \\
\hline \multirow{7}{*}{$\begin{array}{l}\text { Acid Rain, Is It } \\
\text { Dangerous? }\end{array}$} & Determining the solute of a solution & ID; CK & 16 \\
\hline & Determining polyprotic acid based on the knowledge held & ID; CK & 17 \\
\hline & $\begin{array}{l}\text { Determining the nature of the acid solution based on the } \\
\text { knowledge held }\end{array}$ & $\mathrm{ED} ; \mathrm{CK}$ & 18 \\
\hline & $\begin{array}{l}\text { Determining the amount of solute based on the reaction } \\
\text { equation }\end{array}$ & $\mathrm{ED} ; \mathrm{CK}$ & 19 \\
\hline & Determining the $\mathrm{pH}$ of the diluted acid solution & $\mathrm{ED} ; \mathrm{CK}$ & 20 \\
\hline & $\begin{array}{l}\text { Determining the amount of base volume for acid } \\
\text { neutralization }\end{array}$ & $\mathrm{ED} ; \mathrm{CK}$ & 21 \\
\hline & $\begin{array}{l}\text { Formulating conclusions regarding the approximate } \mathrm{pH} \text { of } \\
\text { acid solutions based on } \mathrm{pH} \text { route data }\end{array}$ & EP; EK & 22 \\
\hline \multirow{11}{*}{$\begin{array}{l}\text { The Dilemma of } \\
\text { Using Seawater as } \\
\text { a Replacement for } \\
\text { Generators }\end{array}$} & Evaluating macroscopic observational data & ED; PK & 23 \\
\hline & $\begin{array}{l}\text { Evaluating the sequence of electrical conductivity of a } \\
\text { compound }\end{array}$ & $\mathrm{ED} ; \mathrm{CK}$ & 24 \\
\hline & Evaluating claims based on data and scientific evidence & EP; EK & 25 \\
\hline & Analyzing the properties of the electrolyte solution & $E P ; C K$ & 26 \\
\hline & $\begin{array}{l}\text { Evaluating claims based on evidence and scientific } \\
\text { knowledge }\end{array}$ & ED; EK & 27 \\
\hline & $\begin{array}{l}\text { Explaining experimental data of electrical conductivity } \\
\text { using a substance dissociation diagram }\end{array}$ & EP; PK & 28 \\
\hline & $\begin{array}{l}\text { Explaining experimental data of electrical conductivity } \\
\text { using a substance dissociation diagram }\end{array}$ & $E P ; P K$ & 29 \\
\hline & $\begin{array}{l}\text { Analyzing acetic acid solutions based on scientific } \\
\text { knowledge }\end{array}$ & $E P ; C K$ & 30 \\
\hline & $\begin{array}{l}\text { Describing experimental data of electrical conductivity } \\
\text { using submicroscopic representations }\end{array}$ & $\mathrm{EP} ; \mathrm{PK}$ & 31 \\
\hline & Identifying GAM in $\mathrm{NaCl}$ solution & ID; CK & 32 \\
\hline & $\begin{array}{l}\text { Interpreting experimental data on electrical conductivity } \\
\text { using submicroscopic representations }\end{array}$ & $E P ; P K$ & 33 \\
\hline \multirow{2}{*}{$\begin{array}{l}\text { Pros and Cons of } \\
\text { Online Pharmacy }\end{array}$} & Determining the amount of acid based on data & $\mathrm{ED} ; \mathrm{CK}$ & 34 \\
\hline & $\begin{array}{l}\text { Determining the amount of acid that can be neutralized } \\
\text { based on the data }\end{array}$ & $\mathrm{ED} ; \mathrm{CK}$ & 35 \\
\hline
\end{tabular}




\begin{tabular}{|c|c|c|c|}
\hline Context & Indicator & $\begin{array}{l}\text { Aspects of } \\
\text { Chemical } \\
\text { Literacy* }\end{array}$ & $\begin{array}{l}\text { Item } \\
\text { Number }\end{array}$ \\
\hline \multirow[t]{5}{*}{$\begin{array}{l}\text { Pros and Cons of } \\
\text { Online Pharmacy }\end{array}$} & $\begin{array}{l}\text { Determining the concentration of the species in an acidic } \\
\text { solution }\end{array}$ & EP; CK & 36 \\
\hline & $\begin{array}{l}\text { Analyzing claims based on scientific evidence and } \\
\text { knowledge }\end{array}$ & ED; EK & 37 \\
\hline & Determining the reaction result of a solution & ID; CK & 38 \\
\hline & $\begin{array}{l}\text { Determining the procedure steps for determining the } \\
\text { concentration of a solution }\end{array}$ & $E D ; P K$ & 39 \\
\hline & $\begin{array}{l}\text { Analyzing hydrochloric acid solutions based on reaction } \\
\text { equations and scientific knowledge }\end{array}$ & $\mathrm{EP} ; \mathrm{CK}$ & 40 \\
\hline
\end{tabular}

${ }^{*} \mathrm{CK}=$ Content Knowledge; PK = Procedural Knowledge; EK = Epistemic Knowledge; EP = Explain phenomena scientifically; ED = Evaluate and design scientific inquiry; ID = Interpret data and evidence scientifically.

Limited-scale testing was carried out for high school students (non-sample) in Sidoarjo Regency involving 63 students. The reliability of Cronbach's alpha obtained was 0.793 and 26 items were valid, 14 items were invalid and corrected by discussing them again with the chemistry lecturers.

Wide-scale testing was carried out involving 167 high school students (non-sample). At this stage, an analysis of the validity, reliability, item discrimination index, and item difficulty index were carried out. The reliability of Cronbach's alpha in this wide-scale trial showed a result of 0.833 with a total number 35 valid items, and five invalid items were discarded, resulting in a final draft of 35 items for the chemical literacy test.

\subsection{Sampling}

Respondents of this study were Senior High School students, Natural Science twelfth graders in Sidoarjo Regency. Collecting data was attained through cluster random sampling. From a total of 12 public of Senior High Schools, three of them were randomly selected in Sidoarjo Regency, then from each school, 4-5 classes were randomly selected, each class had 28-40 students. The total number of respondents was then 463 . The respondents were confirmed to have received lessons on chemistry solution according to the indicators developed by direct interviews with the teaching chemistry teacher. Data analysis was carried out by calculating the percentage of respondents' answers, both at the chemical literacy level and the chemical literacy aspects level.

\section{Result and Discussion}

\subsection{Instrument Development Results}

The analysis of instrument development carried out after wide-scale trials, including validity, reliability, item discrimination index, and item difficulty index will be presented below.

\subsubsection{Content Validity}

The content validity was carried out by two expert validators who provided an assessment of the test instruments. The validation percentage based on the Eq. (1) was $91.56 \%$.

$$
P=\frac{\sum x}{n} \times 100 \%(1)
$$

Information: $\mathrm{P}=$ percentage, $\sum \mathrm{x}=$ total assessment score, and $n=$ ideal score (highest score for each aspect $x$ in the number of validators). This means that according to the experts' judgment the items were distributed in very high validity criteria. Therefore, these items were suitable to be used to retrieve data. The chemical literacy test instrument that was declared valid by the expert validator was then amended and tested to determine the validity of the items and their reliability. The trial was conducted twice on high school students (non-sample) in Sidoarjo Regency.

\subsubsection{Item Validity}

The validity of the items was carried out after a wide-scale trial with a total of 167 high 
school students (non-sample) from three schools. From the analysis using IBM SPSS Statistics 22, 35 items were valid, and five items were invalid $(28,30,33,36$, and 40$)$. The invalid items were discarded.

\subsubsection{Reliability}

An instrument is declared reliable if it shows the same measurement results at different times. If the reliability of an instrument is high, then the instrument can be used as a data collection tool. The reliability of Cronbach's Alpha obtained in the first trial was 0.793 while in the second trial (wide scale) it was 0,833 (very high). The results obtained statistically using SPSS statistics 22 indicate that the mean score of students in the first and second trial groups is not significant with the sig value. (2tailed) > 0.05 on the Independent Samples Test on the Equal Variances Assumed, while the value is significant. Levene's Test for Equality of Variances is sig. > 0.05 which indicates that the data variance between the first and second trials is homogeneous. So, it could be stated that the developed chemical literacy instrument was suitable for use to measure the chemical literacy.

\subsubsection{Item Difficulty Index}

The difficulty index is used for the difficulty level of an item or a question. If the difficulty index is in the range 0.00-0.30 then the items are classified as difficult; $0.31-0.70$ items are classified as moderate; and 0.71-1.00 items are classified as easy (Arikunto, 2012). From the 35 valid item questions, 11 questions are classified as difficult $(2,5,11,12,26,31,32,34$, $35,37$, and 39$)$ and 24 medium questions $(1,3$, $4,6,7,8,9,10,13,14,15,16,17,18,19,20,21$, $22,23,24,25,27,29$, and 38), while the average item difficulty index value of 35 items question is 0.376 . Overall, the average value of this difficulty index indicates that the chemical literacy test instrument is at the moderate criterion, even though this value is close to the difficult score limit of 0.30 based on the criteria suggested by Arikunto (2012).

\subsubsection{Item Discrimination Index}

The discrimination index or different power of an item is used to determine the test instrument used to differentiate between upper and lower group students. The criteria for the item discrimination index according to Arikunto (2012) are as follows: $0.00-0.20$ (poor); $\quad 0.21-0.40$ (satisfactory); $0.41-0.70$ (good); and 0.71-1.00 (excellent). In the development of instruments that was carried out by researchers, there were 18 items $(1,4$, $7,10,11,12,14,15,16,18,20,23,24,26,27$, $28,38,42)$ with categories good, 13 questions were in the satisfactory category $(2,3,6,9,19$, $21,22,29,30,32,35,39,41$ ) and four questions were in the poor category. Meanwhile, the average value of the difference between the chemical literacy test instruments, which amounted to 35 questions, was 0.395 , which was in a fairly good range. However, other research states that the discrimination index (D) $>0.30$ means that the item is in a good category (Ding \& Beichner, 2009; Wuttiprom et al., 2009).

\subsection{Chemical Literacy Skills of High School Students on Solution Chemistry}

The final revised instrument used to measure the ability of high school students after the second trial (wide scale). It had a reliability of 0.833 and contained 35 item questions. This test was then distributed to twelfth-grade high school students in Sidoarjo Regency using the cluster random sampling technique. The total respondents were 463 students. The results of measuring students' chemical literacy skills in chemistry solution were presented in Table 3. This result shows that the range of students' chemical literacy scores was 5.71 to 91.43 with an average score of 46.27 .

Table 3. Students' Chemical Literacy Skill

\begin{tabular}{ccccc}
\hline $\mathbf{N}$ & $\begin{array}{c}\text { Total } \\
\text { items }\end{array}$ & $\begin{array}{c}\text { Lowest } \\
\text { Score }\end{array}$ & $\begin{array}{c}\text { Highest } \\
\text { Score }\end{array}$ & Average \\
\hline 463 & 35 & 5.71 & 91.43 & 46.27 \\
\hline
\end{tabular}

Figure 2 is a graph of the students' literacy scores for each aspect of knowledge. The graph shows that the score of students' epistemic knowledge was the lowest between the scores obtained by students in the different aspects of knowledge. Overall, the results reveal that students' chemical literacy is still low based on all aspects of knowledge. These aspects of knowledge in scientific literacy are related to students' understanding 
of the main facts, concepts, and explanatory theories that build the foundation of scientific knowledge (OECD, 2015).

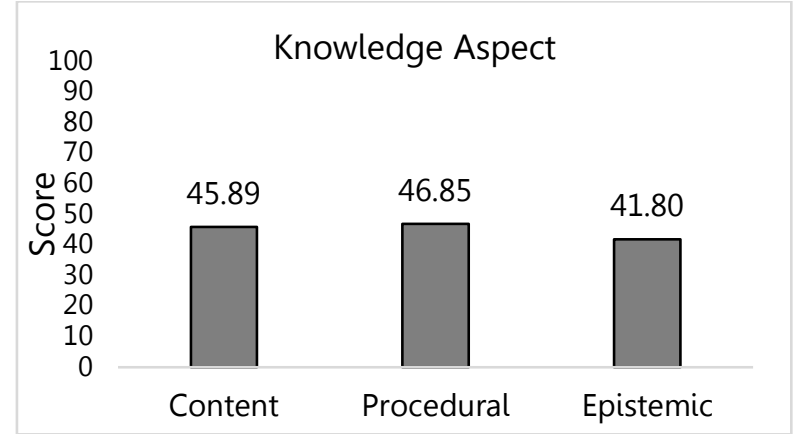

Figure 2. Student Chemical Literacy Scores in each Aspect of Knowledge (Content, Procedural, and Epistemic)

The results of this study were in line with findings of the study conducted by previous researchers (Thummathong \& Tathong, 2016). The average score of the first-year student chemical literacy was 43.58 .

The following was a graph of the student's literacy score for each aspect of competency.

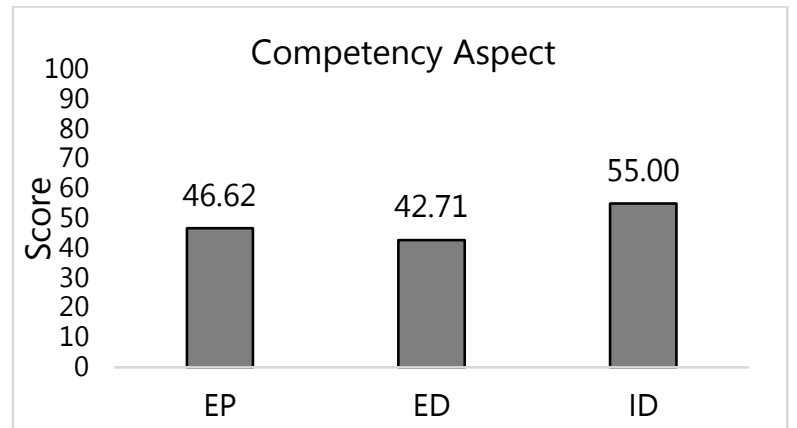

Figure 3. Students' Chemical Literacy Scores in each Aspect of Competency (EP, ED, and ID)

As shown in Figure 3 the results reveal that the students' scores on interpreting data and scientific evidence were the highest. Meanwhile, the EP and ED scores belong to the low category. The average score in the competency aspect was 48.11 with a small difference this result was almost similar the results of the research of Triyani and Azizah (2020) which found that the chemical literacy competency aspect, the average score of students was 60.00 . This difference can be related to the small number of respondents in the previous study, which were 32 students in a science class and the different topic which was chemical equilibrium.

Content knowledge can be defined as the form of knowledge about the universe and technological artifacts (OECD, 2015). In this study, the instrument contained 18 items that stressed the content knowledge. The results indicated that the average score of students' chemical literacy skills in the aspect of content knowledge was 45.89. One of the students' achievements in the aspect of content knowledge can be seen in the following question.

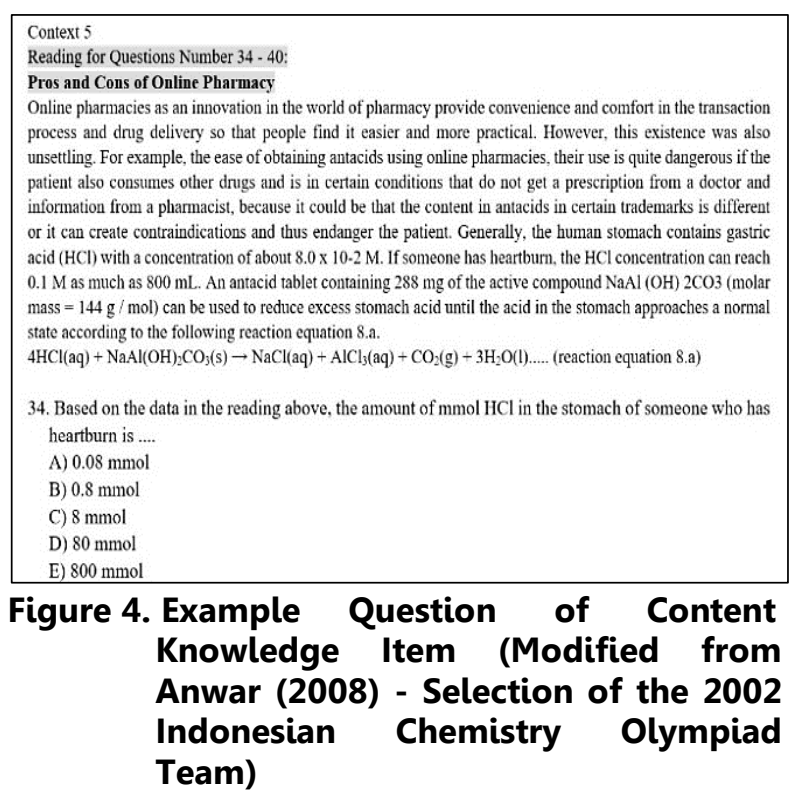

From the question in Figure 4, 42.33\% of students were able to answer correctly by selecting the $D$ option $(80 \mathrm{mmol})$. The question was ranked at the medium cognitive demand category, but this question has the characteristics difficult of an item and has a good value of discrimination index.

Procedural knowledge is knowledge about how ideas are generated (OECD, 2015). There were seven items on the aspects of procedural knowledge in the developed chemical literacy test instrument. The results of this study indicate that the average score of students' chemical literacy skills in the aspect of procedural knowledge was 46.85 . One of the students' achievements in the aspects of 
procedural knowledge can be seen in the following question.

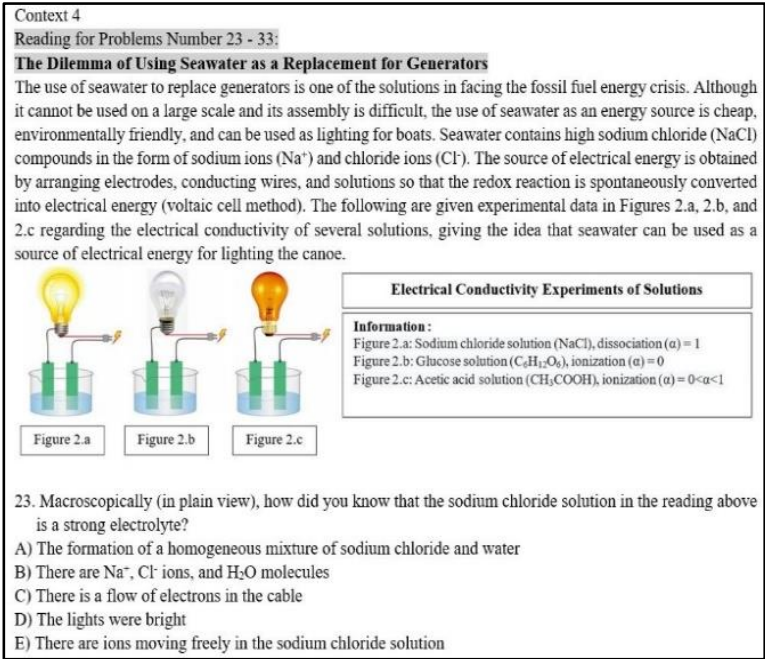

Figure 5. Example Question of Procedural Knowledge Item

In the example in Figure 5, the analysis showed that $57.45 \%$ of students answered correctly by selecting the $D$ option (there was a bright light). The item was at the medium cognitive demand category that was classified as a difficult question and had a good value of discrimination index.

Epistemic knowledge is knowledge about the understanding of the rationale underlying scientific procedures and decisions or considerations for their use (OECD, 2015). There were 10 items on the aspects of epistemic knowledge in the chemical literacy test instrument developed. The results of this study indicate the average score of students' chemical literacy skills in epistemic knowledge aspect was 41.80 .

One of the students' achievements in epistemic knowledge can be seen in Figure 6. In this question, $69.98 \%$ of students answered correctly by selecting the option $\mathrm{C}\left(\mathrm{CO}_{2}\right.$ gas ionizes). The question is medium cognitive demand category with characteristics of at moderate level and had a good value of discrimination index. In this study, it was concluded that students' epistemic knowledge was the lowest in comparison to content or epistemic knowledge. This shows that students have difficulty in analyzing and relating concepts about how knowledge of an idea was scientifically produced.

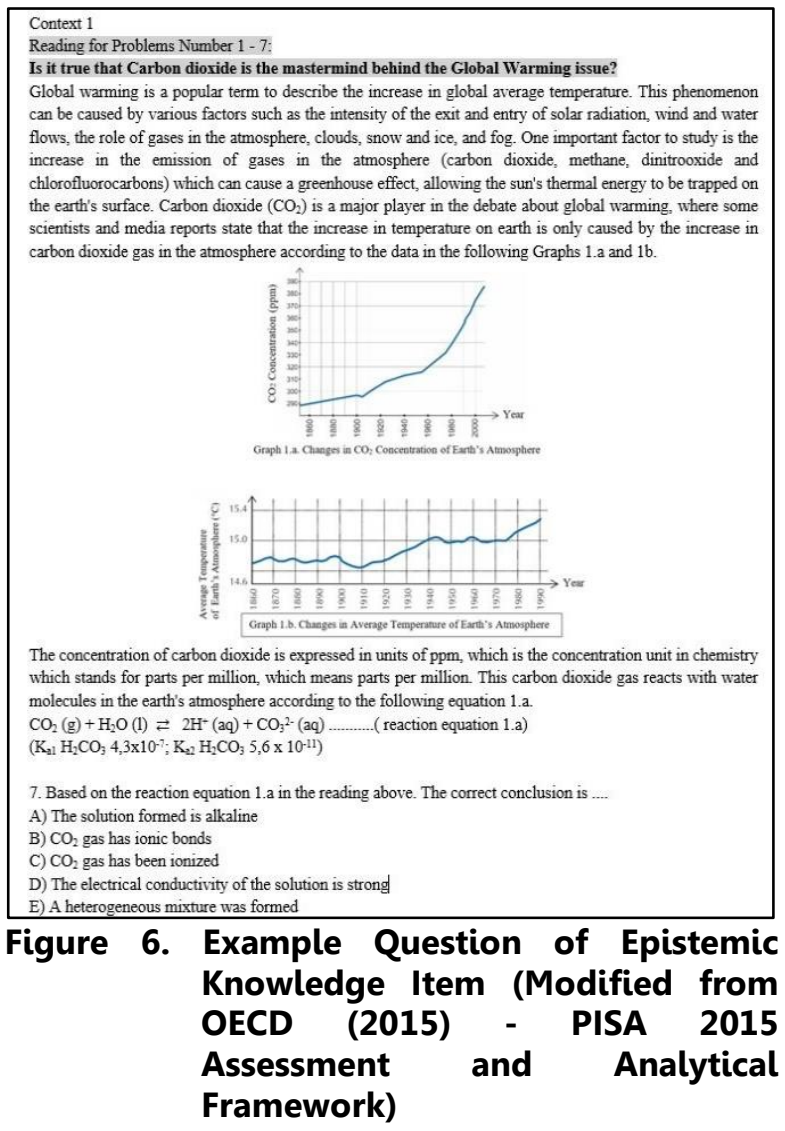

There were eight items of competency aspect with regard to scientific explanation of a phenomena. The results of this study indicate that the average score of students' chemical literacy skills in competence aspects to explain phenomena scientifically was 46.62 .

One of the students' achievements in competency aspect can be seen in Figure 7. In this question, $50.76 \%$ of students answered correctly by selecting the option D (ii and iii). The question was the high cognitive demand. Based on the data from the results of the analysis of the question carried out after the second trial on a large scale, this question had the characteristics of the item that was classified as moderate and had a satisfactory value of discrimination index.

There were 17 items on the competency aspect of evaluating and designing scientific inquiry in the chemical literacy test instrument. The results of this study revealed that the 
average score of students' chemical literacy skills in the competency aspects of evaluating and designing scientific inquiry was 42.71 .

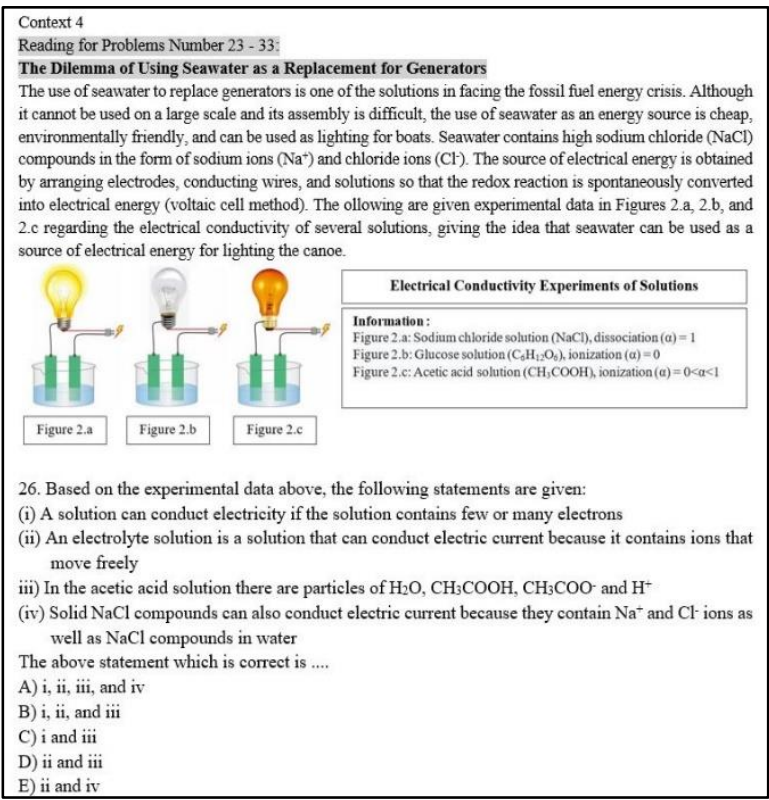

Figure 7. Example Question of Explaining Phenomena Scientifically Item

One of the students' achievements in this competency aspect is shown in Figure 8.

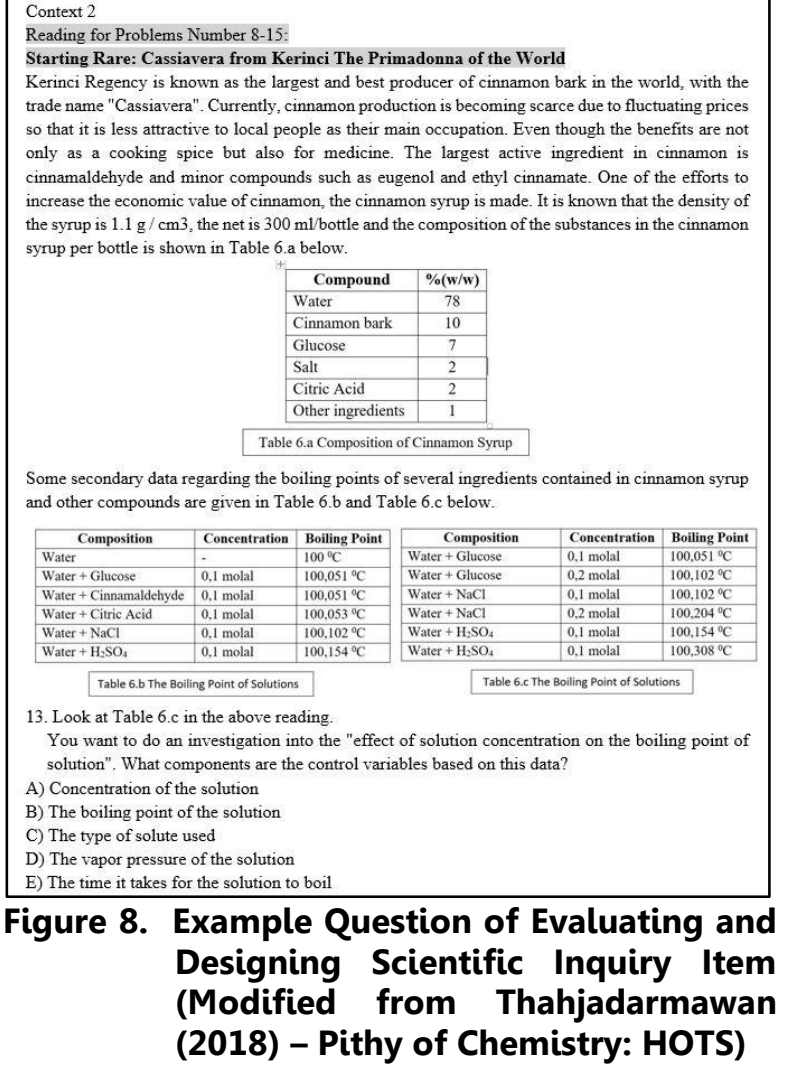

Some secondary data regarding the boiling points of several ingredients contained in cinnamon syrup and other compounds are given in Table $6 . \mathrm{b}$ and Table $6 . \mathrm{c} \mathrm{below}$

Figure 8. Example Question of Evaluating and Designing Scientific Inquiry Item (Modified from Thahjadarmawan (2018) - Pithy of Chemistry: HOTS)

In this question, $42.98 \%$ of students answered correctly in option C (the type of solute used). The question was included in the cognitive demand category: medium.

Based on the data from the results of the analysis of questions carried out after the second trial on a large scale, this question had the characteristics of a question that was classified as moderate and had a good value of discrimination index.

There were ten items on the competency aspect of interpreting data and evidence scientifically in the chemical literacy test instrument that was developed. The results of this study indicate the average score of students' chemical literacy skills in the competency aspect of interpreting scientific data and evidence was 55.00. One of the students' achievements in this competency aspect can be seen in Figure 9 .

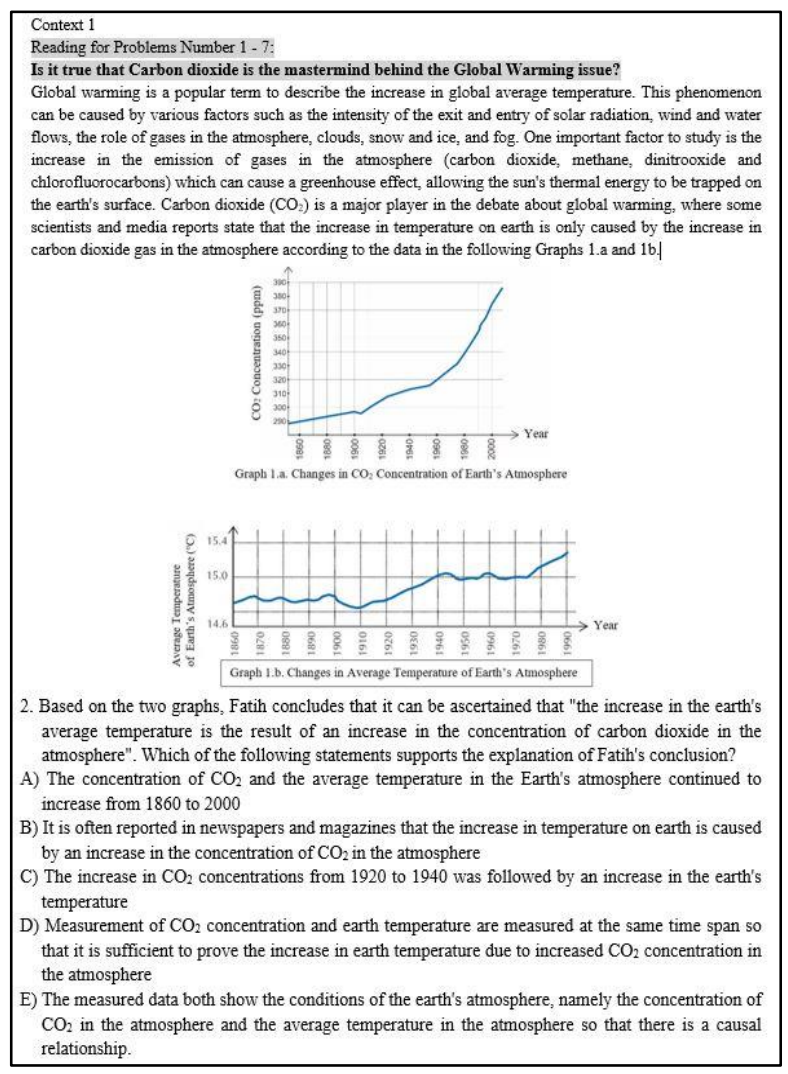

Figure 9. Example Question of Interpreting Data and Evidence Scientifically Item (Modified from OECD (2015) - PISA 2015 Assessment and Analytical Framework) 
Example question can be seen in item 2. In this question, $28.72 \%$ of students answered correctly in option $\mathrm{C}$ (increase in $\mathrm{CO}_{2}$ concentration from 1920 to 1940 followed by an increase in earth temperature). The question was included in the cognitive demand category: medium. Based on the analysis after the second trial on a large scale, this question had characteristics of an item that was classified as difficult and had a satisfactory value of discrimination index.

\section{Conclusion}

This study discussed chemical literacy, especially in the aspects of knowledge and competence using chemical literacy test instrument on the chemistry solution topic. The test that was developed consisted of 35 valid items with a Cronbach's Alpha reliability of 0.833 . This reliability coefficient considered at a very good value. Therefore, this test instrument was implemented to explore the chemical literacy skills of high school students in the Sidoarjo Regency.

The survey showed that the average score of students on this test was 46.27. This value indicated that students' chemical literacy still low and suggested the need for measures to be improved. This can be used as an evaluation of the learning carried out because the questions in the chemical literacy test instrument refer to the KD K-13 indicator. These findings suggest the need for ideas to develop chemical literacy among high school students in Indonesian context.

The average score of chemical literacy from the lowest to the highest in terms of knowledge and competence can be summarized as the following, epistemic knowledge (41.80), content knowledge (45.89), procedural knowledge (46.85), competence to evaluate and design scientific investigations (42.71), explain phenomena scientifically (46.62), and interpret data and scientific evidence (55.00).

This research has important implications for chemistry education: (1) multiple-choice chemical literacy tests can be used in chemistry education and needs to be developed to involve the attitude aspect. (2) for the respondents it seems that they were not accustomed to working on scientific literacy questions and also questions in the context of issues that exist in society; (3) students' chemical literacy must be improved by learning that supports students in literacy; (4) a chemical literacy test should be used to assess student achievement so that they were trained to solve daily life problems scientifically. Some solutions to improve students' scientific literacy include applying environmental-based creative and collaborative learning, inquiry-based learning, metacognition training, authentic scientific inquiry, socio-critical learning, and problem solving, learning based on scientific processes, use of scientific texts, learning strategy approaches integrated, and argumentative methods (Karademir \& Ulucinar, 2017). The study of Huann-shyang et al. (2012) found that there was a relationship between attitudes and scientific literacy, namely the interest, enthusiasm, and participation of students in learning science to improve their scientific literacy skills. Scientific literacy can be improved by increasing laboratory activities and equipping students with activities that emphasize affective aspects. Besides that, the existence of adequate scientific literacy instruments, both science as a whole and science in specific fields can be increase students' scientific literacy (Muntholib, 2020).

\section{References}

Ad'hiya, E., \& Laksono, E. W. (2018). Development and validation of an integrated assessment instrument to assess students' analytical thinking skills in chemical literacy. International Journal of Instruction, 11(4), 241-256. https://doi.org/10.12973/iji.2018.11416 a

Arikunto, S. (2012). Dasar-dasar evaluasi pendidikan edisi 2. Jakarta: PT Bumi Aksara. 
Benjamin, T. E., Marks, B., Demetrikopoulos, M. K., Rose, J., Pollard, E., Thomas, A., et al. (2015). Development and validation of scientific literacy scale for college preparedness in STEM with freshman from diverse institutions. International Journal of Science and Mathematics Education, 15(4), 607-623. https://doi.org/10.1007/s10763-0159710-x

Borg \& Gall. (1983). Educational research: An introduction. New York and London: Longman Inc.

Bossér, U., Lundin, M., Lindahl, M., \& Linder, C. (2015). Challenges faced by teachers implementing socio-scientific issues as core elements in their classroom practices. European Journal of Science and Mathematics Education, 3(2), 159176. Retrieved from https://files.eric.ed.gov/fulltext/EJ11078 35.pdf

Celik, S. (2014). Chemical literacy levels of science and mathematics teacher candidates. Australian Journal of Teacher Education, 39(1), 1-15. http:// dx.doi.org/10.14221/ajte.2014v39n1.5

Cigdemoglu, C., \& Geban, O. (2015). Improving students' chemical literacy levels on thermochemical and thermodynamics concepts through a context-based approach. Chemistry Education Research and Practice, 16(2), 302-317.

https://doi.org/10.1039/C5RP00007F

Cigdemoglu, C., Arslan, H.O., \& Cam, A. (2017). Argumentation to foster pre-service science teachers' knowledge, competency, and attitude on the domains of chemical literacy of acids and bases. Chemistry Education Research and Practice, 18(2), 288-303. https://doi.org/10.1039/C6RP00167J

Demir, E. (2016). Characteristics of 15-year-old students predicting scientific literacy skills in Turkey. International Education
Studies,

9(4),

99-107.

https://doi.org/10.5539/ies.v9n4p99

Ding, L., \& Beichner, R. (2009). Approaches to data analysis of multiple-choice questions. Physical Review Physics Education Research, 5(2), Article 020103. https://doi.org/10.1103/PhysRevSTPER. 5.020103

Dragos, V., \& Mih, V. (2015). Scientific literacy in school. Procedia - Social and Behavioral Sciences, 209, 167-172, https://doi.org/10.1016/j.sbspro.2015.1 1.273

Fives, H., Huebner, W., Birnbaum, A. S., \& Nicolich, M. (2014). Developing a measure of scientific literacy for middle school students. Sciences Education, 98(4) 549-580. https://doi.org/10.1002/sce.21115

Huann-shyang, L., Zuway-R. Hong \& Tai-Chu, $H$. (2012). The role of emotional factors in building public scientific literacy and engagement with science. International Journal of Science Education, 34(1), 2542. https://doi.org/10.1080/09500693.2010. 551430

Karademir, E., \& Ulucinar, U. (2017). Examining the relationship between middle school students' critical reading skills, science literacy skills and attitudes: A structural equation modeling. Journal of Education in Science, Environment and Health, 3(1), 29-39.

https://doi.org/10.21891/jeseh.275669

Kemdikbud. (2016a). Permendikbud No. 22 Tahun 2016 tentang Standar Proses Pendidikan Dasar dan Menengah. Jakarta: Depdiknas.

Kemdikbud. (2016b). Permendikbud No. 24 Tahun 2016 tentang Kompetensi Inti dan Kompetensi Dasar Pelajaran pada Kurikulum 2013. Jakarta: Depdiknas.

Jurnal Tadris Kimiya 6, 1 (June 2021): 1-15 
Muntholib, Mayangsari, J., Pratiwi, Y. N., Muchson, Joharmawan, R., Yahmin, \& Rahayu, S. (2018). Development of simple multiple-choice diagnostic test of acid-base concepts to identify students' alternative conceptions. Proceedings of the 1st Annual Internasional Conference on Mathematics, Science, and Education (IcoMSe 2017), 218, 251-268. https://doi.org/10.2991/icomse17.2018.45

Muntholib. (2018). Efektivitas scientific inquiry-based lecturing dalam meningkatkan literasi kimia dan views about scientific inquiry mahasiswa kimia. Disertasi, Fakultas Matematika dan Ilmu Pengetahuan Alam: Universitas Negeri Malang.

Muntholib, Ibnu, H., Rahayu, S., Fajaroh, F., Kusairi., \& Kuswandi, B. (2020). Chemical literacy: Performance of first year chemistry students on chemical kinetics. Indonesian Journal of Chemistry, 20(2), 468-482.

https://doi.org/10.22146/ijc.43651

Mutlu, A., \& Sesen, B. A. (2015). Development of a two-tier diagnostic test to assess undergraduates' understanding of some chemistry concepts. Procedia - Social and Behavioral Sciences, 174, 629-635. https://doi.org/10.1016/j.sbspro.2015.0 1.593

Nahadi, F. H., \& Ulum, M. (2018). Development and validation of reasoning-based multiple-choice test for measuring the mastery of chemistry. Journal of Engineering Science and Technology, 13(6), 1476-1488. https://doi.org/10.1063/1.4983989

Nurjananto, N., \& Kusumo, E. (2015). Pengembangan instrumen penilaian autentik untuk mengukur kompetensi peserta didik materi senyawa hidrokarbon [Development of authentic assessment instruments to measure student competencies of hydrocarbon compounds]. Jurnal Inovasi Pendidikan Kimia, 9(2), 1575-1584. Retrieved from https://journal.unnes.ac.id/nju/index.ph p/JIPK/article/view/4825/3993

Organization for Economic Co-operation and Development (OECD). (2015). PISA 2015: Draft Science Framework. Paris: OECD Publishing.

Organization for Economic Co-operation and Development (OECD). (2016). PISA 2015 Assessment and Analytical Framework: Science, Reading, Mathematics, and Financial Literacy. Paris: OECD Publishing.

Organization for Economic Co-operation and Development (OECD). (2018). PISA 2018: Database. Paris: OECD Publishing.

Rahayu, S. (2017). Promoting the 21st century scientific literacy skills through innovative chemistry instruction. $A / P$ Conference Proceedings, 1911(1), 020025. https://doi.org/10.1063/1.5016018

Rahayu, S., Treagust, D. F., Chandrasegaran, A. L., Kita, M., \& Ibnu, S. (2011). Assessment of electrochemical concepts: a comparative study involving senior high school students in Indonesia and Japan. Research in Science and Technological Education, 29(2), 169-188. https://doi.org/10.1080/02635143.2010. 536949

Sadhu, S., \& Laksono, E. W. (2018). Development and validation of an integrated assessment for measuring critical thinking and chemical literacy in chemical equilibrium. International Journal of Instruction, 11(3), 557-572. http://dx.doi.org/10.12973/iji.2018.1133 $8 \mathrm{a}$

Shwartz, Y., Ben-Zvi, R., \& Hofstein, A. (2006). Chemical literacy: What does this mean to scientist and school teacher? Journal of Chemical Education, 83(10), 1557- 
1561.

https://doi.org/10.1021/ed083p1557

Shwartz, Y., Ben-Zvi, R., \& Hofstein, A. (2006). The importance of involving high-school chemistry teachers in the process of defining the operational meaning of "Chemical Literacy". International Journal of Science Education, 27(3), 323344.

https://doi.org/10.1080/0950069042000 266191

Thahjadarmawan, E. (2018). Pithy of chemistry: HOTS. Yogyakarta: Parama Ilmu.

Thummathong, R., \& Thathong, K. (2018). Chemical literacy levels of engineering students in Northeastern Thailand. Kasetsart Journal of Social Sciences, 39(3), 478-487. https://doi.org/10.1016/j.kjss.2018.06.00 9

Triyani, R. \& Azizah, U. (2020). Training of science literacy skills in chemical equilibrium through implementation guided inquiry learning. Jurnal Tadris Kimiya, 5(1), 35-47. https://doi.org/10.15575/jtk.v5i1.7550

Vieira, R. M., \& Vieira, C. T. (2014). Fostering scientific literacy and critical thinking in elementary science education. International Journal of Science and Mathematics Education, 14, 659-680. https://doi.org/10.1007/s10763-0149605-2

Wattanakasiwich, P., Taleab, P., Sharma, M. D., \& Johnston, I. D. (2013). Development and implementation of a conceptual survey in thermodynamics. International Journal Innovation Science and Mathematics Education, 21(1), 29-53. Retrieved from https://openjournals.library.sydney.edu. au/index.php/CAL/article/viewFile/6459 $/ 7493$

Wuttiprom, S., Sharma, M. D., Johnston, I. D., Chitaree, R., \& Soankwan, C. (2009). Development and use of a conceptual survey in introductory quantum physics. International Journal of Science Education, 31(5), 631-654. https://doi.org/10.1080/0950069070174 7226

Yustin, D. L., \& Wiyarsi, A. (2019). Students' chemical literacy: A study in chemical bonding. Journal of Physics: Conference Series, 1397, 012036. https://doi.org/10.1088/17426596/1397/1/012036 